\title{
Management Decisions of Russian-language Newspapers in Germany in the Time of Structural Media Crisis
}

\author{
Anna S. Smoliarova \\ PhD in Political Sciences, St. Petersburg State University, a.smolyarova@spbu.ru \\ Kamilla R. Nigmatullina \\ PhD in Political Sciences, St. Petersburg State University, k.nigmatullina@spbu.ru
}

Doi:10.5901/mjss.2015.v6n6s2p68

\begin{abstract}
Media industry went through two crises in XXI century and the last one is labeled as "structural". Firstly it concerns the print media which have to develop a new business model in the Internet age. The owners, editors and researchers suggested several concepts how the print media industry could override the crises. While the print media in Western countries mostly declines the ethno-cultural media feel more stable but still face the challenges of the Internet age. Despite increased scholarly attention to ethnic media, the management of ethnic media has not been explored in a comparative way. In this article we discuss the complex of problems the owners and editors of Russian-language newspapers published in modern Germany handle with and compare their view of media crises with the discussion within editors of national print media. The study based on semi-structured interviews with publishers of Russian-language print media points at similarities and differences between national and ethno-cultural press. The ethno-cultural print media particularly face similar problems, hence, the specific nature of this segment of the media market influences decisions made by media managers.
\end{abstract}

Keywords: media management, media crises, ethno-cultural media, Russian-language press

\section{Introduction}

Ethno-cultural media today occupy an important place in the media market in many developed countries. In some cases researchers have ever stopped talking about them as minority media. For example, the size of the audience of Hispanic media in Los Angeles has become comparable with the English-speaking audience (Cottle, 2000). However, the management of ethnic and cultural media, to which we refer all the different types of media to the audience segmented along ethnic, linguistic, cultural principle - diasporal, immigrant, minority etc. - studied to a lesser extent, particularly in relation to European cases (Knobloch-Westerwick \& Coates 2006, Jin \& Kim 2011, Moran 2006). Media producers are explored in the context of institutional structures and main scholar attention is paid to the media content; ethnic media users; and the societal context of audiences and producers (Johnson, 2010). Ethnic marketing forms a separate research field and represents Economic studies rather than Media studies (Block \& Kouba 2006; Kumanyika 2008; Korgaonkar, Petrescu \& Karson, 2015).

Ethno-cultural media traditionally face three groups of problems (Matsaganis, Katz, \& Ball-Rokeach, 2011): 1) generation change narrows the audience; 2) narrowed advertising/investments landscape reduces the spectrum of development possibilities; 3 ) low level of professionalism complicates the competition with other media - published by the majority in the host and home countries. Simultaneously ethno-cultural media are challenged by the general problems of mass media in the XXI century. We describe in the following sections main trends in the negative development of mass media market, explore the strategies of Russian-language print media publishers and conclude in which aspects do their vision correlate with the national media managers.

\section{Theoretical Framework}

\subsection{Structural shift in media industry}

It should be taken into consideration that economic crisis came together with structural shift in media industry in general. Competitive environment has been enlarged not only to the extent of industry of entertainment. Average time of media 
consuming per day increased to 9-11 hours out of 24. In USA figure is even bigger: in 2013 James E. Short believed that by 2015 Americans will consume both traditional and digital media for over 1.7 trillion hours, an average of approximately 15 and a half hours per person per day (2013). Media companies compete for this spare time with Internet, IT industry, mass culture industry, etc. From this point, nowadays media industry experiences not only economical pressure but it is also influenced by crucial changes in media consumption. For example Philip M. Napoli (2013) emphasizes a new role of audience which does not only consume but contribute as well.

Another influence is caused by long-term business strategies of media companies. Still they mostly depend on advertising model that is respectively caused by unwillingness of major advertisers to change their perception of changes in media consumption. This situation does not allow media companies to change their strategies as crucial as they wish. At the same time European media industry is based on public funding (public service media) which makes up to two thirds of the total budget (Josef Trappel et al., 2015). That means that European business models depend on audience behavior very hard.

One of the proven anti-crisis strategies is also caused by fragmentation of audiences that provoked emerging of niche media market. Huang and Wang (2014: 161) claim that drawing from Anderson's (2006) long tail economic model, a business that can offer more niche products, in addition to popular ones, is expected to be most successful. For online news institutions advertising was still the main revenue model, as audiences did not pay for most online content. All in all, the results of Huang and Wang (2014:173) research revealed that online news institutions have responded to the changing market trend of segmentation and niches by deploying a long tail economy in terms of content, service, and participation variety through the aid of information and Internet technologies.

Global media market shows declining of print revenues and very little growth of online revenues at the same time. Moreover, going online costs are still not so low because they are tied with expensive technologies that bring convergence into newsrooms. That is why "going online" strategy does not work globally. For instance, for German market it is still obvious that cross-media processes - on both organizational and production level - are not professionalized yet. Media companies tried to enter the new mobile publishing market quickly without clearly considering the platforms specifics and holistic cross-media strategies. This was proven in Wolf and Godulla research (2014) which states that no matter which strategy stands behind multi-platform activities, media enterprises hardly act innovative: the offline media product mostly has priority (86\%), online-first is barely established (17\%).

German media earned "a record-breaking income" from advertising in the 2000 (Litvinenko, 2010) notwithstanding they went through two media crises in last ten years. Already in 2001 the income from advertising was down by 14\% compared to the previous year and continued to decrease by more than 10 percent every year (Heymann, 2003). The situation had improved to the 2006 (Litvinenko, 2010) but not for long time. When the crisis in the beginning of the XXI century was triggered by fall of so called 'new economy' the second stage of the decline in media industry was related to the world economic recession in 2008 - 2009. The main challenge faced by editors is to develop a new business model that let the media, firstly the quality press, to survive under new conditions (D'Inka 2009). German media come to several decisions that can be divided into four groups (Litvinenko, 2010): 1) media concentration 2) policy of economy (transformation of the traditional structure of income and expenses) 3) marketing innovations 4) acquisition of young customers (school projects).

\subsection{Internet usage: Russian-speaking residents in Germany}

The concerns about the shift of the audience to the free information sources in Internet relate also to the audience consisting of immigrants from the former USSR. It is crucial for the German media landscape which is more stable comparing to US media market also because the traditional loyalty of the audience to the print media.

Russian-speaking residents in Germany use Internet more active than the German society at the average: the share of Internet users among immigrants from the former USSR is bigger than $70 \%$ comparing to $65 \%$ of Internet users in Germany at the average (Kissau, 2008). The younger the resident is the less is the share of print media consumers. Only $12 \%$ of the people from 12 to 19 years old read newspapers or magazines regularly while $73 \%$ in this age use Internet and $86 \%$ are TV-consumers (Heft \& Paasch-Colberg, 2013). In the group of Russian residents in the ager from 20 to 29 years old the share is definitely higher $-27 \%$.

Level of education of Russian-speaking media consumers in Germany varies in the inverse proportion to the share of the print media audience and in the direct proportion to the share of online-news readers. Only $12 \%$ of people finished the first school grade and $36 \%$ of students follow the news in the Internet. The share of print media consumers within people younger than 12 years old is $10 \%$ bigger than within students.

Russian-speaking community in Germany is interested in news not only from the former USSR but from other 
countries because the diaspora is dispersed and the audience tends to follow the media coverage about events concerning Russian-speaking world. Russian-speaking immigrants communicate via Internet with immigrants all over the world more active than people in Turkish community in Germany - 10\% and $3 \%$ of the contacts in Internet reciprocally (Kissau, 2008). Quite the opposite persons living in Germany with roots in Turkey use Internet more active for contacts within Germany and outside the immigrant community: among contacts of Russian-speakers the share of the German citizens is $20 \%$, among Turkish-speakers - about $35 \%$ (Kissau, 2008). The data driven from the content-analysis of websites targeting on immigrants supports these tendencies: Russian-language group of Internet portals piblishes more foreign and global news comparing to the Turkish and Kurdish websites for German residents (Kissau, 2008).

\section{Methodology}

The semi-structured interviews with the editors, publisher and owners of Russian-language media were conducted in 2012. The meetings were organized in the publishing houses, an average interview took 1 hour. The respondents were asked to describe the audience of their media products, especially in terms of the level of integration into the host society, the structure of income (sources first of all), the level of convergence within the publishing house, the profile of Internet presence, the efforts to attract the younger audience and the perspectives of their publishing house and Russianlanguage media in general. The most well developed publishing houses were included into the sample: Russian Germany (RusMedia Publishing House), MK in Germany, Partner GMbH, LTC Verlag. Werner Media Group went into liquidation since summer 2012 but the quotes of one of the chief-editors are also included. Russian media landscape in Germany is diversified therefore the expert interviews were also conducted with the publisher of a regional newspaper Evening Newspaper (Augsburg), the founder of a website portal Berlin 24, and the publisher of a regional magazine Ours Bayern. Based in the previous research we included questions concerning the decisions about aging of the audience, developing a new business model and stuff policy. In the following sections we discussed the results dividing the answers in these three subsections.

\section{Results}

\subsection{Lack of young readers}

The readers of the weekly newspaper Russian Germany are typically older than 35 years (RG 2012). Readers under 30 make up only $11 \%$, while the core group consists on people aged 30 to 49 years (47\%). Readers aged 50 to 60 years and 60 and older are presented almost equally (20\% and 22\%, respectively).

According to the publisher, $39 \%$ of the audience of the newspaper Russian Germany are people with incomes above 2,500 euros per month, 28\% earn from 2000 to 2500 euros per month (Rusmedia, 2014). According to the publisher of Ours Bayern typical audience of a typical Russian-language editions are those "who goes into the Russian shops - old men who are nostalgic, and young people".

Her words were confirmed by the founder of the web-portal Berlin 24, who find the audience amorphous, indifferent to the issues of German life. The basis of the subscribers are the "elderly people without language (knowledge of German language - authors) and the Internet": according to him, people acquired the language of the host country consume German media.

All editors and publishers noted difficulties in attracting young people, although journalists differ in their approach to this issue. Representatives of publishing houses Werner Media and Partner see themselves as part of a general trend "print media are dying". They refer to the fact that young people in general are not in the habit of reading newspapers or magazines, regardless of language and the desire to maintain a bilingual combined with dual ethnic and cultural identity. "Even 15 years in one form or another we will breathe", explains the chief editor of Europa-Express, weekly newspaper published by the Werner Media. He sees another disability to expand the audience of Europa-Express: "Young audience does not understand our author's language - with plenty of Soviet time jokes or connotations".

Editors of Europa-Express and Partner noted also that the youth less than the older generation needs the Russianlanguage press: they speak German better and prefer to receive information both political and news-to-use from German sources. Representatives of LTC Verlag and RusMedia believe that audiences need to grow, and she starts to consume the print media sooner or later. LTC Verlag relies on Internet products: the publisher house develops information services on the Internet to find an alternative source of income to the time when print media finally ceases to be popular. The Partner magazine overcomes geographic isolation via Internet: according to the CEO, 25\% of visits to the site belong to users who live outside of Germany, including Russia and Ukraine. 
MK in Germany launches special products. The chief editor of Lifeln: "The flow between Germany and Russia does not end, both students and professionals continue to come, so the Russian language will remain". According to her, the main task of the publishing house in these circumstances is to be ready to develop new products. The magazine MyCity is an example, targeting on the audience of 21 to 40 years. It focuses on the career development, current events in the region of Frankfurt, photo reports from events, news, music and film industry. The only general-interest newspaper confidently announced the availability of young readers is Evening Newspaper published in Augsburg. The publisher noted that the newspaper attracts older readers "because of their children, who are happy to use the publication as a source of free information".

The founder of the portal Berlin 24 says, the Internet has affected the needs of the audience: "in early 2000-s the newspapers were the only source of horoscopes and advertising. Now you can find Russian television broadcast schedule via Internet". Consequently, the potential reader sees no need to bring home a gratis newspaper from the Russian store, while earlier people became acquainted with the content of other headings because they required a TV program. The founder of the portal Berlin 24 sees perspectives for the development of Russian-language media in the projects of citizen journalism like exemplary Russian projects You-Reporter or Ridus.

\subsection{Lack of German advertisers}

Russian-language publications are trying to look for German advertisers. "Cooperation with German advertisers is difficult because of the low professional level of the Russian media", says the editor of the publishing house MK in Germany. Ours Bayern is one successful example of cooperation with the German advertisers: the publisher signed an advertising contract with a major outlet in Bavaria where the magazine is also distributed. Internet-access and the gradual adaptation of the language reduces the need for the Russian-language press, resulting in falling share of income previously brought by subscribers. Evening Newspaper editor stresses that the advertising in Russian-language media is "very expensive and essentially it is branding". The political cooperation with local authorities helps: Evening Newspaper editor reminds on a joint Russian-Turkish-German edition launched by Augsburger Allgemeine and under the auspices of the Christian Democratic Union of Germany. "Their goal is to pull the electorate into the elections, our - to get the German advertisers", he says. Russian Germany also publishes political advertising of German parties during the election campaign.

The publisher of Ours Bayern estimates entrepreneurs as the main source for the profit and focus on this segment of the audience facing new problems in the distribution of the magazine. She aims to find contacts in German firms, ministries of transport structures. The Partner magazine also aims to expand the audience, "fighting for working people, families who communicate in a German environment," says CEO of the magazine. Prosperity of the readers allows the publisher to work more effectively with the advertising sources.

\subsection{Lack of professionalism}

There is a lack of people who got professional education as journalists. For example, journalists of the newspaper Russian Germany differ by education: "among more than one hundred freelance writers there are linguists, lawyers, even the prosecutor", says the executive editor. Hence, according to him, journalists working for RusMedia have direct contacts with German politicians and experts. According to the CEO of the magazin, only one of five people who created the Partner magazine can be regarded as a professional journalist and the concept of the magazine was developed by another person. Today professional journalists make up about a third of the Partner's editorial board. Publisher of Ours Bayern magazine criticize colleagues because "they acquire bad taste to the people" reprinting materials from the Internet. The publisher of the Evening Newspaper thinks, "it's a never-ending circle: while the newspaper is not a good journalistic product, young journalists educated in Germany would not have a desire to join the team".

Another way to deal with the lack of professionalism is cooperation with Russian media. The section of the newspaper "One-sixth" covering the new from the former Soviet republics was filled by the content of Russian editions signed the contracts with RusMedia but now the editorial policy includes production of the original content in this part of the newspaper. The Partner magazine cooperates with media organization Deutsche Welle, for example, its political commentator Nikita Zholkver. "One of the strengths of our magazine is the high intellectual level of the content so we invite such renowned authors as Greta lonkis and Marina Agranovskaya", says CEO of the magazine. The magazine publishes also Russian authors working for Echo of Moscow and Novaya Gazeta. 


\section{Conclusion}

Crisis of 2008 showed to global media industry several ways to survive: 1) reducing costs of producing content; 2) reducing staff; 3) cutting branches with no revenues; 4) cutting media division as a part of big non-media company; 5) looking for non-advertising based business models. Along with these global media industry strategies, we can observe specific ways of overriding crisis in terms of content production: involving audience in producing, establishing paywalls online, attracting native advertising investors, changing strategy form "print-first" to "web-first", etc. However, the essence of media production has not changed totally.

Publishers of Russian-language press in Germany do not implement most of these strategies although the problems they are challenged by are more complicated. Next generation of Russian speakers use other informational sources, hence, the publishing houses are threatened with extinction if they will not find the way to fulfill the needs of their future audience. Lack of professionalism and disinterest of German advertisers exacerbate the situation because these factors narrow potential resources for further development.

Three decision models are presented on the Russian-language segment of German media landscape. The Partner magazine and Russian Germany foster orientation on the intellectual, well-educated audience interested in locally produced opinion journalism. MK in Germany (and partially the founder of Berlin 24) relies on innovative forms of print products specially targeting young audience and developing the reading habit and audience's loyalty. Finally, Ours Bayern is oriented on the temporal migration and tourists.

\section{Limitations}

In 2015 we understand that processes recorded in 2012 have developed and transformed. New circumstances, especially increase of online consumption and online revenues, caused certain changes in media strategies. However, it is obvious that diaspora media do not reflect all changes in global market so quickly. We understand that German media for Russian diaspora represent more peculiarities than general trends. At the same time we believe that found results support many observations in changing media strategies.

Further research may be focused on comparing niche media for different kind of diaspora in Europe and on dynamics in media strategies in crises.

\section{Acknowledgements}

Research funded by a grant from the School of Journalism and Mass Communications, St. Petersburg State University (4.23.1665.2014 "Transformation of foreign russian-language journalism within national media systems"). Conducting of the expert interviews was supported by a ZDES-DAAD individual grant for young researchers.

\section{References}

Anderson, C. (2006). The long tail: Why the future of business is selling less of more. New York, NY: Hyperion.

Block, D., \& Kouba, J. (2006). A comparison of the availability and affordability of a market basket in two communities in the Chicago area. Public Health Nutrition, 9 (7), 837-845.

Cottle, S. (2000). Ethnic Minorities and the Media: Changing Cultural Boundaries. Open University Press.

Heft, A., \& Paasch-Colberg, S. (2013). Media Cultures of Young Turkish Migrants and German Resettlers in Germany. Global Media Journal: German edition, 3 (1). [Online] Available: http://www.db-thueringen.de/servlets/DerivateServlet/Derivate-27628/GMJ5_ Heft Paasch-Colberg final.pdf (April 14, 2015).

Heymann, E. (2003). The media industry will resume growth only gradually. Deutsche Bank Research. August 21, 2003.

Huang, J. S., \& Wang W.-C. Application of the Long Tail Economy to the Online News Market: Examining Predictors of Market Performance. Routledge. 2014.

Jin, D. Y., \& Kim, S. (2011). Sociocultural Analysis of the Commodification of Ethnic Media and Asian Consumers in Canada. International Journal of Communication, 5, 552-569.

Kissau, K. (2008). The Internet Sphere of Russian and Turkish Immigrants in Germany. Presentation on 27.09.2008 at the conference "Media on the Move - Migranten, Minoritäten und Medien" of the Forum Media and Development, Bonn/Germany.

Knobloch-Westerwick, S., \& Coates, B. (2006). Minority models in advertisements in magazines popular with minorities. Journalism \& Mass Communication Quarterly, 83 (3), 596-614.

Korgaonkar, P., Petrescu, M., \& Karson, E. (2015). Hispanic-Americans, Mobile Advertising and Mobile Services. Journal of Promotion Management, 21 (1), 107-125.

Kumanyika, S.K. (2008). Environmental influences on childhood obesity: Ethnic and cultural influences in context. Physiology and 
Behavior, 94 (1), 61-70.

Litvinenko, A.A. (2010). German newspapers in the XXI century: from crisis to modernization. Moscow, KMK.

Matsaganis, M., Katz, V.S., \& Ball-Rokeach, S.J. (2011). Understanding Ethnic Media: Producers, Consumers, and Societies. Thousand Oaks, CA: Sage.

Mensing, D. (2007). Online revenue business model has changed little since 1996. Newspaper Research Journal, 28, 22-37.

Moran, K. C. (2006). Is changing the language enough? The Spanish-language alternative' in the U.S.A. SAGE Publications, 7(3), 389405.

Napoli Philip M. (2013) Audience Evolution: New Technologies and the Transformation of Media Audiences. Columbia University Press.

Rusmedia data for advertisers. (2014). [Online] Available: http://rusmedia.de/upl_files/96d0eb0cd6392f37c3a6e85c90b45b66.pdf (May 10, 2015).

Short James E.. (2013) How Much Media? 2013 Report on American Consumers. University of Southern California, 7.

Trappel Josef, Steemers Jeanette, Thomass Barbara. (2005) European Media in Crisis: Values, Risks and Policies. Routledge, 184.

Wolf, C., \& Godulla, A. (2014). Cross-media Strategies in German Media Enterprises Publishing Concepts, Organizational Adjustments, and Content Adaption. Abstract from European Media Management Association 2014. [Online] Available: http://www.mediamanagement.eu/ocs/index.php/emma/emma2014/paper/view/107 (April 14, 2015). 